\title{
ANTIFERTILITY ACTION OF 5-HYDROXY- TRYPTAMINE AT THE TIME OF IMPLANTATION: MECHANISM IN THE RAT AND ACTION IN THE MOUSE, GUINEA-PIG AND RABBIT
}

\author{
P. B. MARLEY \\ Department of Pharmacology, The School of Pharmacy, \\ 29-39 Brunswick Square, London WC1 $\mathcal{N} 1 A X$
}

(Received 28th December 1972)

\begin{abstract}
Summary. The antifertility effect of 5-hydroxytryptamine creatinine sulphate (5-HT), 20 to $40 \mathrm{mg} / \mathrm{kg}$ subcutaneously, given about the time of implantation, was investigated in four species having between them three modes of implantation. The compound had a marked antifertility effect in rats once implantation had occurred but did not have any effect in mice, which have a similar mode of implantation, or any significant effect in guinea-pigs and rabbits on or around the day of implantation.

In rats, antifertility effects similar to those seen with $5-\mathrm{HT}$ were obtained by occluding the uterine vasculature for $1 \mathrm{hr}$, i.e. maximum effects on the day of implantation and little effect before this. In view of this and the finding that the effects of 5-HT were considerably reduced by the intraperitoneal injection of $40 \mathrm{mg}$ dipyridamole $/ \mathrm{kg} 15 \mathrm{~min}$ later, it was concluded that 5-HT produced its effects by reducing blood flow in the uterus.
\end{abstract}

\section{INTRODUCTION}

The mechanism by which 5-hydroxytryptamine (5-HT) exerts its antifertility effect during the early stages of pregnancy has received little attention, although the mechanism is by no means clear. In mice and rats, single subcutaneous injections of 5-HT have little or no effect before implantation but marked antifertility effects subsequently, especially on the day of implantation (Marley, 1969). There are two reasons for believing the mechanism of this action to be different from the mechanism later in pregnancy, when $5-\mathrm{HT}$ is thought to reduce blood flow in the uterus (Robson \& Sullivan, 1966; Marley, Robson \& Sullivan, 1967). First, uterine vascular occlusion experiments in the rat at different stages of pregnancy showed that the preimplantation stages were the most susceptible to damage (Franklin \& Brent, 1964) whereas 5-HT had least antifertility effect during those stages. Second, progesterone reduced the antifertility effect in the mouse (Lindsay, Poulson \& Robson, 1963) even if given some hours after the 5-HT injection (Marley, 1969), suggesting that it antagonized a luteolytic action of 5-HT.

These points have been examined in the present work. In addition, the effects 
of 5-HT have been examined in two species which have different modes of implantation from the mouse and rat (eccentric implantation; Amoroso, 1952), to assess its importance in the action of 5-HT. The species used were the guinea-pig (interstitial implantation) and the rabbit (centric implantation).

\section{MATERIALS AND METHODS}

The animals used in this study were LACA mice (Tuck), Wistar rats (Tuck), Dunkin-Hartley guinea-pigs (Olac) and Dutch rabbits (Hyline). The mice and rats were maintained on a 14 -hr light/10-hr dark lighting regimen, and were fed on Oxoid breeding diet, whereas the guinea-pigs and rabbits were exposed to daylight plus artificial light between 09.00 and 17.00 hours and were fed on Oxoid SGI diet. The day of mating was called Day 1 . Each doe was mated with two bucks whereas the females of the other species were housed with males until mating occurred.

Doses of 5-HT refer to the creatinine sulphate salt (May and Baker) which contains $43.5 \%$ of the base. Solutions were made in saline on the day of injection and were given subcutaneously before mid-day, unless otherwise stated. The dose volumes were $10 \mathrm{ml} / \mathrm{kg}$ for mice and $4 \mathrm{ml} / \mathrm{kg}$ for the others. Progesterone (BDH) was diluted to $10 \mathrm{mg} / \mathrm{ml}$ with arachis oil and a subcutaneous injection of $0.5 \mathrm{ml}$ was given daily. Dipyridamole (Persantin, Boehringer Ingelheim) was dissolved in 5\% ascorbic acid in saline and given in a dose volume of $3 \mathrm{ml} / \mathrm{kg}$. The effects of $5-\mathrm{HT}$ about the time of implantation were compared in the four species. The days of implantation were: Day 5 in the mouse and Day 6 in the rat, confirmed by the uptake of Trypan blue into the implantation site (Psychoyos, 1960); Day 7 in the guinea-pig (Blandau, 1949; Deanesly, 1971) and Day 8 in the rabbit (Adams, 1960). The animals were injected either on the morning of the day of implantation or a day or so before or after implantation. In the rat, these other times were Day 5 and Day 7. The equivalent stages in pregnancy for the guinea-pig were taken as being late Day 5 and Day 8, respectively and, for the rabbit, Days 7 and 9, respectively.

The effects on pregnancy were examined in the following way. Mice and rats were killed near to term. Guinea-pigs were subjected to laparotomy after Day 15 under fluothane anaesthesia and were subsequently left to litter. Rabbits were left to litter and the numbers of fetuses were counted.

\section{Uterine vascular occlusion}

Rats were anaesthetized with ether, ventral and lateral abdominal incisions were made and bulldog clips were placed across the uterine artery and vein at the cervical and the ovarian ends of the left uterine horn. The ovarian blood flow was not occluded by this procedure. The incisions were closed and the rats were allowed to regain consciousness. After a set time of occlusion, the rats were anaesthetized with ether, the incisions were opened and the colour of the uterus was noted before the bulldog clips were removed. Uteri which were not dark red to blue in colour were considered to have been incompletely occluded and the rat was excluded from the study. 


\section{RESULTS}

Effect of 5-HT on pregnancy

Mice. No antifertility effects were seen with doses of $40 \mathrm{mg} \mathrm{5-HT/kg}$, given once or twice on the day of implantation (Table 1). This was true whether the mice were fed on a breeding or a maintenance diet, or were exposed to $8 \mathrm{hr}$ or to $14 \mathrm{hr}$ light each day (Table 1). All mice treated with $40 \mathrm{mg} \mathrm{5-HT/kg}$ were sedated and had peripheral vasodilatation.

Table 1. Lack of effect of 5-HT on pregnancy when given on the day of implantation in mice subjected to various lighting and dietary conditions

\begin{tabular}{|c|c|c|c|c|}
\hline Diet & $\begin{array}{l}\text { Lighting } \\
\text { (hr/day) }\end{array}$ & Drug* & No. pregnant & $\begin{array}{l}\text { No. of fetuses } \\
\text { (mean } \pm \text { S.E.) }\end{array}$ \\
\hline Breeding & 14 & $\begin{array}{l}\text { Saline } \\
\text { 5-HT }\end{array}$ & $\begin{array}{l}20 / 22 \\
18 / 22\end{array}$ & $\begin{array}{l}9 \cdot 0 \pm 0 \cdot 8 \\
8 \cdot 2 \pm 1 \cdot 0\end{array}$ \\
\hline Breeding & 14 & $\begin{array}{l}\text { Saline } \times 2 \\
5-\mathrm{HT} \times 2\end{array}$ & $\begin{array}{l}4 / 7 \\
6 / 7\end{array}$ & $\begin{array}{l}5 \cdot 7 \pm 2 \cdot 2 \\
9 \cdot 1 \pm 4 \cdot 8\end{array}$ \\
\hline $\begin{array}{l}\text { Maintenance } \\
\text { (41B) from } \\
\text { birth }\end{array}$ & 14 & $\begin{array}{l}\text { Saline } \\
\text { 5-HT }\end{array}$ & $\begin{array}{r}11 / 12 \\
9 / 12\end{array}$ & $\begin{array}{l}8 \cdot 6 \pm 1 \cdot 1 \\
6 \cdot 8 \pm 1 \cdot 5\end{array}$ \\
\hline Breeding & 8 ( 3 to 4 weeks) & $\begin{array}{l}\text { Saline } \\
\text { 5-HT }\end{array}$ & $\begin{array}{l}7 / 10 \\
8 / 10\end{array}$ & $\begin{array}{r}9 \cdot 6 \pm 2 \cdot 2 \\
10 \cdot 3 \pm 1 \cdot 9\end{array}$ \\
\hline Breeding & $\begin{array}{l}8 \text { ( } 4 \text { weeks) then } \\
14 \text { ( } 1 \text { to } 2 \text { weeks) }\end{array}$ & $\begin{array}{l}\text { Saline } \\
5-\mathrm{HT}\end{array}$ & $\begin{array}{l}16 / 20 \\
16 / 20\end{array}$ & $\begin{array}{l}8 \cdot 5 \pm 1 \cdot 2 \\
8 \cdot 4 \pm 1 \cdot 1\end{array}$ \\
\hline
\end{tabular}

Significance, $P>0.05$ in all cases, comparing 5-HT with saline group.

* The 5-HT was given in a dose of $40 \mathrm{mg} / \mathrm{kg}$.

Rats. Marked antifertility effects in rats were observed following a dose of

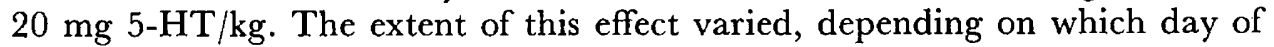
pregnancy it was given. Rats injected on Day 6, the day of implantation, suffered the greatest embryotoxicity, having significantly fewer fetuses and a greater number of resorption sites than the others (Table 2). Those injected

Table 2. Effect of day of injection on the effect of 5-HT on pregnancy in the rat

\begin{tabular}{|c|c|c|c|c|}
\hline Treatment & $\begin{array}{l}\text { Day of } \\
\text { treatment }\end{array}$ & $\begin{array}{c}\text { No. } \\
\text { pregnant }\end{array}$ & $\begin{array}{l}\text { No. of fetuses } \\
\text { (mean } \pm \text { S.E.) }\end{array}$ & $\begin{array}{c}\text { No. of resorptions } \\
(\text { mean } \pm \text { S.E. })\end{array}$ \\
\hline $20 \mathrm{mg} / \mathrm{kg}$ & $\begin{array}{l}5 \\
6 \\
7\end{array}$ & $\left.\begin{array}{c}10 / 10 \\
5 / 10 \\
9 / 10\end{array}\right\} *$ & $\left.\begin{array}{r}11 \cdot 7 \pm 0.5 \\
1 \cdot 1 \pm 0 \cdot 4 \\
8 \cdot 6 \pm 1.7\end{array}\right\} * * * *$ & 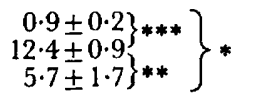 \\
\hline $40 \mathrm{mg} / \mathrm{kg}$ & $\begin{array}{l}5 \\
6 \\
7\end{array}$ & $\begin{array}{l}8 / 10 \\
4 / 10 \\
9 / 10\end{array}$ & $\left.\begin{array}{l}8 \cdot 7 \pm 1 \cdot 5 \\
1 \cdot 3 \pm 1 \cdot 0 \\
6 \cdot 0 \pm 1 \cdot 4\end{array}\right\} * * * *$ & 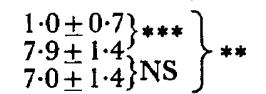 \\
\hline $\begin{array}{l}2 \times 20 \mathrm{mg} / \mathrm{kg} \\
(1-\mathrm{hr} \text { interval })\end{array}$ & $\begin{array}{l}5 \\
6 \\
7\end{array}$ & $\left.\begin{array}{l}8 / 10 \\
2 / 10 \\
7 / 10\end{array}\right\} *$ & 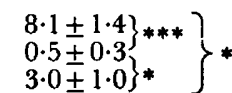 & $\left.\begin{array}{c}1 \cdot 2 \pm 0.4 \\
10.4 \pm 0 \cdot 9 \\
6.2 \pm 1 \cdot 1\end{array}\right\} * * * *$ \\
\hline
\end{tabular}

Significance by Student's $t$ test and $\chi^{2}$ test. ${ }^{*} P<0.05, * * P<0 \cdot 01, * * * P<0.001$, all others $P>0.05$. 
1 day later, on Day 7, had significantly more resorptions and fewer fetuses than those injected on Day 5 . The latter suffered comparatively little toxicity (Table 2 ). These results show that the sensitivity to $5-\mathrm{HT}$ varies on 3 consecutive days of pregnancy, the order of sensitivity being Day $6>$ Day $7>$ Day 5 .

Increasing the dose of 5 -HT from 20 to $40 \mathrm{mg} / \mathrm{kg}$ did not significantly increase the embryotoxicity (Table 2).

Guinea-pigs and rabbits. No significant antifertility effect was observed in guinea-pigs with a dose of $20 \mathrm{mg} 5-\mathrm{HT} / \mathrm{kg}$ or in rabbits with a dose of $40 \mathrm{mg} / \mathrm{kg}$ (Table 3), though the groups used were not very large. It is clear, however, that these species did not show the same sensitivity to $5-\mathrm{HT}$ as the rat.

Table 3. Effect of 5-HT on pregnancy in the guinea-pig and rabbit

\begin{tabular}{|c|c|c|c|}
\hline & Treatment & No. pregnant & $\begin{array}{l}\text { No. of fetuses } \\
\text { (mean } \pm \text { S.E. }\end{array}$ \\
\hline Guinea-pigs & $\begin{array}{l}\text { Saline, Day } 5,7 \text { or } 8 \\
\text { 5-HT, } 20 \mathrm{mg} / \mathrm{kg} \\
\text { Day } 5^{*} \\
\text { Day 6* } \\
\text { Day } 7 \\
\text { Day 8* }\end{array}$ & $\begin{array}{l}8 / 8 \\
4 / 5 \\
\\
6 / 6 \\
4 / 6 \\
4 / 6 \\
5 / 6\end{array}$ & $\begin{array}{l}3 \cdot 4 \pm 0.5 \\
2 \cdot 8 \pm 0.7 \\
\\
3 \cdot 2 \pm 0.3 \\
2 \cdot 2 \pm 0.7 \\
1 \cdot 8 \pm 0.7 \\
2 \cdot 2 \pm 0.5\end{array}$ \\
\hline Rabbits & $\begin{array}{l}\text { Saline, Day } 8 \\
5 \text {-HT } 40 \mathrm{mg} / \mathrm{kg} \\
\text { Day } 7 \\
\text { Day } 8 \\
\text { Day } 9\end{array}$ & $\begin{array}{l}4 / 4 \\
3 / 4 \\
4 / 4\end{array}$ & $\begin{array}{l}10 \cdot 0 \pm 2 \cdot 0 \\
8 \cdot 0 \pm 2 \cdot 2 \\
5 \cdot 0 \pm 2 \cdot 1 \\
8 \cdot 0 \pm 1 \cdot 1\end{array}$ \\
\hline
\end{tabular}

No means significantly different from animals injected with saline $(P>0.05)$.

* Injected in the late afternoon, others in the morning.

Investigation of the mechanism of action of 5-HT in rats

Progesterone. The ability of progesterone to reverse the antifertility effect of 5-HT given on Day 6 of pregnancy was investigated by giving progesterone, daily, beginning on Day 6 , in amounts sufficient to maintain pregnancy in ovariectomized rats. The same progesterone treatment was given to salinetreated rats in order to exclude the possibility that the exogenous progesterone plus the intrinsic progesterone had a deleterious effect. As can be seen from the results in Table 4, the supplementary progesterone did not overcome the antifertility effects of 5-HT.

Dipyridamole. A considerable reduction in fetal mortality was seen when dipyridamole was given intraperitoneally in a dose of $40 \mathrm{mg} / \mathrm{kg} 15 \mathrm{~min}$ after the 5-HT injection (Table 4).

\section{Effects of uterine vascular occlusion}

The blood supply to one uterine horn was occluded for $\frac{1}{2}$ to $4 \mathrm{hr}$ in groups of rats on Days 5, 6 or 7 of pregnancy. At term, the number of live fetuses in each horn was expressed as a percentage of the number of corpora lutea in the 
Table 4. The effect of progesterone or dipyridamole on the antifertility effects of a single injection of 5-HT, given on Day 6 of pregnancy in the rat

\begin{tabular}{|c|c|c|c|}
\hline $\begin{array}{l}\text { Treatment on } \\
\text { Day } 6\end{array}$ & $\begin{array}{c}\text { No. of rats } \\
\text { pregnant }\end{array}$ & $\begin{array}{c}\text { No. of } \\
\text { fetuses } \\
\text { (mean } \pm \text { S.E.) }\end{array}$ & $\begin{array}{c}\text { No. of } \\
\text { resorptions } \\
\text { (mean } \pm \text { S.E. })\end{array}$ \\
\hline $\begin{array}{l}\text { Ovariectomy }+ \text { Prog* } \\
\text { Saline } \\
\text { 5-HT } \dagger \\
5-\mathrm{HT} \dagger+\text { Prog* } \\
\text { Saline }+ \text { Prog* } \\
5-\mathrm{HT} \dagger+\text { Dipyridamole } \ddagger \\
5-\mathrm{HT} \dagger+\text { Ascorbic acid } \$\end{array}$ & $\begin{array}{r}10 / 10 \\
10 / 10 \\
4 / 10 \\
7 / 10 \\
8 / 10 \\
11 / 11 \\
9 / 11\end{array}$ & 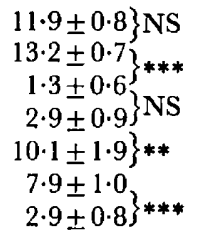 & $\begin{array}{l}\left.\begin{array}{l}1 \cdot 2 \pm 0 \cdot 7 \\
0 \cdot 8 \pm 0 \cdot 3 \\
7 \cdot 5 \pm 1 \cdot 5 \\
8 \cdot 7 \pm 1 \cdot 8 \\
1 \cdot 9 \pm 1 \cdot 6\end{array}\right\} * * \\
\left.\begin{array}{l}3 \cdot 6 \pm 0 \cdot 7 \\
8 \cdot 4 \pm 1 \cdot 0\end{array}\right\} * *\end{array}$ \\
\hline
\end{tabular}

ipsilateral ovary. Ovaries of control and occluded sides had, respectively, $6 \cdot 3+2 \cdot 0$ and $6 \cdot 2+2 \cdot 1($ mean + S.D., $n=108)$ corpora lutea at term.

Comparing occluded with control horns, there was no significant reduction in the percentage of corpora lutea represented by live fetuses at term following a $\frac{1}{2}$-hr occlusion on any of the days. This result also established that the manipulative procedures associated with the occlusion did not cause any untoward effect. With 1-hr occlusions, there was no significant effect when this was performed on Day 5 but there were marked effects on Days 6 and 7. Although the response appeared to be greater on Day 6 than Day 7, the values were not significantly different (Table 5).

With longer periods of clamping, differences between days became smaller and not significant. The resistant 14 to $28 \%$ of animals in the 2 - and 4 -hr groups were usually due to a viable fetus at the cervical end of the uterus. This was the most difficult area to occlude completely and in several cases the colour here suggested that there had been incomplete occlusion.

Table 5. Sensitivity to the embryotoxic effects of occlusion of the uterine vasculature on different days of pregnancy in the rat

\begin{tabular}{c|c|c|c|c|c}
\hline \multirow{2}{*}{ Treatment } & \multirow{3}{*}{ Day of occlusion } & \multicolumn{5}{|c}{$\%$ of corpora lutea represented by live fetuses after various occlusion } \\
& & \multicolumn{4}{|c}{ periods (mean \pm S.E.) } \\
\cline { 2 - 6 } & & $\frac{1}{2} h r(n=10)$ & $1 h r(n=10)$ & $2 h r(n=10)$ & $4 h r(n=6)$ \\
\hline Occluded horn & 5 & $81 \pm 9$ & $77 \pm 6)^{* *}$ & $23 \pm 11^{* * *}$ & $19 \pm 10^{* *}$ \\
& 6 & $84 \pm 8$ & $36 \pm 1\}^{* * *}$ & $26 \pm 10^{* * *}$ & $14 \pm 6 * *$ \\
& 7 & $85 \pm 5$ & $61 \pm 9 * *$ & $28 \pm 7 * * *$ & $24 \pm 3^{* * *}$ \\
Contralateral & 5 & $88 \pm 8$ & $83 \pm 8$ & $83 \pm 5$ & $81 \pm 8$ \\
horn & 6 & $92 \pm 3$ & $87 \pm 6$ & $86 \pm 5$ & $92 \pm 6$ \\
& 7 & $80 \pm 8$ & $98 \pm 3$ & $84 \pm 10$ & $92 \pm 3$ \\
\hline
\end{tabular}

Significance compared with contralateral horn, except where indicated, using Student's $t$ test, $* * P<0.01 ; * * * P<0.001$; all others $P>0.05$. 


\section{DISCUSSION}

This study has shown that there is considerable species variation in the sensitivity to the antifertility effects of 5-HT about the time of implantation. With doses between 20 and $40 \mathrm{mg} / \mathrm{kg}$, the effect is weak or non-existent in mice, guinea-pigs and rabbits but high in rats. By contrast, at later stages of pregnancy 5-HT has marked antifertility effects in mice $(40 \mathrm{mg} / \mathrm{kg}$; Robson \& Sullivan, 1966), rats (10 mg/kg, Day 18, Craig, 1966; or Day 10, Marley et al., 1967 ) and rabbits (2 mg/kg, Days 23 to 30 , Poulson, Botros \& Robson, 1960).

The lack of effect of 5-HT in the mouse at the time of implantation is puzzling since it disagrees with previous findings (Marley, 1969) and unpublished results. The mice in the previous study had been fed on a maintenance diet (41B) and the lighting was a mixture of natural light and artificial illumination. It was thought that an antifertility effect might be uncovered if these conditions were reproduced, but this was not the case. It is possible that Tuck LACA mice used in the present study were resistant to the antifertility effects of 5-HT although they were sedated by the 5-HT as before. Previously, albino, LACA (Coombehurst), Horne (Fison's) and mice bred from various sources were used but no significant difference was found between them.

The mechanism of action of 5-HT has not been established unequivocally from these experiments. Injections of 5-HT into the third ventricle of the rat inhibit the release of $\mathbf{L H}$ in ovariectomized rats, in which there is a high release of LH (Schneider \& McCann, 1970), and the same might be true of 5-HT given systemically to pregnant rats. Pregnancy can be interrupted up to Day 12 if LH levels fall and this effect can be reversed by progesterone (Madhwa Raj \& Moudgal, 1970). In the present experiments, progesterone was unable to reverse the effects of 5-HT. This suggests that the critical site of action of 5-HT was neither in the central nervous system nor in the ovary.

In late pregnancy, 5-HT only acts peripherally (Robson \& Sullivan, 1966). In early pregnancy (Days 1 to 6 ) in the mouse, while at first a central site of action was postulated (Lindsay et al., 1963), later work by the same group showed that 5-HT was acting peripherally at this time (Robson, Sullivan \& Wilson, 1969). The experiments reported here also suggest that 5-HT acts peripherally.

The most likely mechanism of action is that 5-HT decreases blood flow in the uterus, as it does a few days later during the period of embryogenesis (Marley et al., 1967). Antifertility effects similar to those caused by 5 -HT were produced by occluding the uterine blood supply for $1 \mathrm{hr}$. Injections of 5-HT produced their greatest effect on Day 6, a lesser effect on Day 7 and little effect on Day 5 and similarly $1 \mathrm{hr}$ of vascular occlusion had marked effects on Days 6 and 7 and no effect on Day 5. The reversal by dipyridamole is also consistent with 5-HT acting peripherally to reduce blood flow since dipyridamole dilates blood vessels. It also potentiates the vasodilator actions of adenosine, which is released in situations of severe hypoxia (Hashimoto, Kumakura \& Tranemura, 1964; Parratt \& Wadsworth, 1972).

Unequivocal proof that 5-HT acts in this way would require measurements of blood flow around the implantation site in the endometrium. It is noteworthy, 
however, that others have reached similar conclusions regarding the mechanism of action of 5-HT on other reproductive processes. The inhibition of ovulation produced by $5-\mathrm{HT}$, thought by Labhsetwar (1971) to be mediated through a central mechanism, can be antagonized by dipyridamole. From this and other evidence, Wilson \& McDonald (1974) conclude that 5-HT inhibits ovulation by reducing blood flow in the ovary. Similarly, the testicular disruption which occurs in rats given daily injections of $5-\mathrm{HT}$ is thought to be due to testicular ischaemia (Boccabella, Salgado \& Alger, 1962).

The results with 5-HT and a 1-hr period of uterine vascular occlusion demonstrate the differences in the susceptibility of the embryo about the time of implantation but the explanation for the phenomenon is open to conjecture. The nutritive requirements or supplies to the embryo may be modest before implantation and critical on the day of implantation (Day 6). The rate of passage of [ $\left.{ }^{22} \mathrm{Na}\right]$ sodium into the uterine lumen on Day 6 is reduced by the processes of implantation or decidualization (Marley \& Robson, 1972). If the passage of other substances are affected in the same way, any reduction in blood flow would result in a correspondingly greater reduction in supply of nutrients on this day than on the days preceding or following implantation.

The results of uterine vascular occlusion reported here differ from those of Franklin \& Brent (1964). They claimed that a greater embryotoxicity occurred if the occlusion was performed on the days before implantation rather than following it, whereas the results reported here with a 1-hr period of occlusion clearly establish that there was no effect on Day 5 , the day before implantation, but marked effects subsequently. Franklin \& Brent's results are complicated by the fact that, in occluding blood flow by placing haemostatic forceps across the uterus, they also crushed the uterus. The toxicity before implantation could have been due to this rather than to the cessation of blood flow and their results should be interpreted cautiously.

\section{ACKNOWLEDGMENTS}

I thank Mr P. Karmakar for his skilled technical assistance and Dr Wilson and Dr McDonald for discussing their results on dipyridamole. I also thank $\mathrm{Dr}$ Maxwell, May \& Baker Ltd, for a gift of 5-HT and Dr Bell, Boehringer Ingelheim Ltd, for a gift of dipyridamole.

\section{REFERENCES}

Adams, C. E. (1960) Studies on prenatal mortality in the rabbit, Oryctolagus cuniculus: the amount and distribution of loss before and after implantation. F. Endocr. 19, 325.

Amoroso, E. C. (1952) Placentation. In: Marshall's Physiology of Reproduction, Vol. 2, p. 244. Ed. A. S. Parkes. Longmans Green, London.

Blandau, R. J. (1949) Observations on implantation of the guinea-pig ovum. Anat. Rec. 103, 19.

Boccabella, A. V., Salgado, E. D. \& Alger, E. A. (1962) Testicular function and histology following serotonin administration. Endocrinology, 71, 827.

CRAIG, J. M. (1966) Mechanism of serotonin induced abortion in rats. Archs Path. 81, 257.

DeanesLy, R. (1971) The differentiation of the decidua at ovo-implantation in the guinea-pig contrasted with that of the traumatic deciduoma. 7. Reprod. Fert. 26, 91.

Frankin, J. B. \& BRent, R. L. (1964) The effect of uterine vascular clamping on the development of rat embryos three to fourteen days old. J. Morph. 115, 273. 
Hashimoto, K., Kumakura, S. \& Tranemura, I. (1964) Mode of action of adenine, uridine, cytidine nucleotides and 2,6-bis(diethanolamino)-4,8-dipiperidino-pyrimido-(5,4-d)pyrimidine on the coronary, renal and femoral arteries. Arzneimittel-Forsch. 14, 1252.

Labhsetwar, A. P. (1971) Effect of serotonin on spontaneous ovulation in rats. Nature, Lond. $229,203$.

Lindsay, D., Poulson, E. \& Robson, J. M. (1963) The effect of 5-hydroxytryptamine on pregnancy. 7. Endocr. 26, 85.

Madhwa RaJ, H. G. \& Moudgal, N. R. (1970) Hormonal control of gestation in the intact rat. Endocrinology, 86, 874.

Marley, P. B. (1969) Antifertility effect of 5-hydroxytryptamine at the time of implantation in mice and rats. F. Endocr. 43, xxxiv.

Marley, P. B. \& Robson, J. M. (1972) Effect of decidual cell-inducing stimuli on the passage of sodium into the uterine lumen of the rat. 7 . Reprod. Fert. $28,341$.

Marley, P. B., Robson, J. M. \& Sullivan, F. M. (1967) Embryotoxic and teratogenic action of 5-hydroxytryptamine: mechanism of action in the rat. Br. J. Pharmac. 31, 494.

Parratt, J. R. \& WADsworth, R. M. (1972) The effects of dipyridamole on the myocardial vasodilator actions of noradrenaline, isoprenaline and adenosine, Br. 7. Pharmac, 46, 585.

Pourson, E., Botros, M. \& Robson, J. M. (1960) The effects of 5-hydroxytryptamine and iproniazid on pregnancy. 7. Endocr. 20, xi.

Psychoyos, A. (1960) La réaction déciduale est précédée de modifications précoces de la perméabilité capillaire de l'utérus. C.r. Séanc. Soc. Biol. 154, 1384.

Robson, J. M. \& Sullivan, F. M. (1966). Analysis of actions of 5-hydroxytryptamine in pregnancy. J. Physiol., Lond. 184, 717.

Robson, J. M., Sullivan, F. M. \& Wilson, C. (1969) The effect of naturally occurring amines on pregnancy in mice. 7 . Endocr. 45, viii.

Schneider, H. P. G. \& McCann, S. M. (1970) Mono- and indolamines and control of LH secretion. Endocrinology, 86, 1127.

Wilson, C. \& McDonald, P. G. (1974) Inhibitory effect of serotonin on ovulation in the adult rat. J. Endocr. 60 (in press). 